\title{
Sealant Powder Dosage Form
}

National Cancer Institute

\section{Source}

National Cancer Institute. Sealant Powder Dosage Form. NCI Thesaurus. Code C149894.

Solid sterile preparation consisting of one or more powders intended to be applied directly onto the intended site (e.g. a lesion) to form a hemostatic agent and/or tissue glue after contact with an appropriate fluid (e.g. blood). 